\title{
Brittle asthma
}

\author{
O. Toungoussova1, M.P. Foschino Barbaro2, L.M. Esposito1, \\ G.E. Carpagnano2, F. G. Salerno1, R.W. Dal Negro3, A. Spanevello1,2
}

ABSTRACT: Brittle asthma. O. Toungoussova, M.P. Foschino Barbaro, L.M. Esposito, G.E. Carpagnano, F.G. Salerno, R. W. Dal Negro, A. Spanevello.

Brittle asthma is a clinical phenotype of the disease at the severe end of the spectrum. Type 1 brittle asthma is characterised by a maintained wide PEF variability $(>40 \%$ diurnal variation for $>50 \%$ of the time over a period of at least 150 days) despite considerable medical therapy including a dose of inhaled steroids of at least $1500 \mu \mathrm{g}$ of beclomethasone or equivalent. Type 2 brittle asthma is characterised by sudden acute attacks occurring in less than three hours without an obvious trigger on a background of apparent normal airway function or well controlled asthma. Mechanisms behind the development of brittle asthma include smooth muscle contraction and edema of the air- ways, which are supported by chronic airway inflammation. Allergy reactions, impairment of local immunity, respiratory infections, psycho-social disorders and reduced perception of worsening airway function are the risk factors for brittle asthma. The diagnosis is based on the analysis of specific symptoms, role of triggers, personal or family history, measurement of lung function and PEF monitoring. Pharmacological treatment of type 1 brittle asthma in addition to the high doses of inhaled and/or oral steroids and bronchodilators includes subcutaneous injections of $\beta_{2}$ agonist and inhalation of long acting $\beta_{2}$ agonist. The treatment of patients with type 2 brittle asthma includes exclusion of allergen exposure, identification of triggers, self management and management of acute attacks.

Monaldi Arch Chest Dis 2007; 67: 2, 102-105.

Keywords: Brittle asthma, severe asthma, peak expiratory flow.

1 Fondazione Salvatore Maugeri, Care and Research Institute, Cassano Delle Murge, Bari,

2 Department of Respiratory Diseases, University of Foggia, Foggia,

3 Lung Department, Orlandy Hospital, Bussolengo, Verona, Italy

Correspondence: Antonio Spanevello, Fondazione Salvatore Maugeri, Care and Research Institute, Via per Mercadante km 2, 70020 Cassano Delle Murge, Bari, Italy; e-mail: aspanevello@fsm.it

Asthma is characterised by chronic airway inflammation, variable airflow obstruction and airway hyper-responsiveness, accompanied by recurrent episodes of coughing, wheezing, breathlessness and chest tightness [1]. Airflow limitation is usually relieved at least partially either spontaneously or by bronchodilators.

Over the years, different classifications of asthma based on the evaluation of etiological factors, pathology, symptoms, clinical phenotypes and severity of the disease were described [2-4]. The standard classification based on symptoms and lung function defines the severity of asthma (mild intermittent, mild persistent, moderate persistent and severe persistent). Patients with the same severity of asthma can be characterised by different clinical phenotypes of the disease. Brittle asthma is one of these phenotypes at the severe end of the spectrum $[5,6]$. Brittle asthma is also referred to in scientific literature as unstable or unpredictable asthma [7]. Patients with brittle asthma can have mild intermittent symptoms progressing suddenly to severe, life threatening attacks, which are difficult to control [5].

The present review aims to present updated knowledge on brittle asthma, a particular phenotype of asthma disease, with a special emphasis on definition, classification, mechanisms, risk factors, clinical picture, diagnosis and management.

\section{Definition}

The term "brittle asthma" has been used since 1977, when it was introduced by Turner-Warwick to describe patients with chaotic variations of peak expiratory flow (PEF) leading to severe attacks of asthma, which were difficult to control with usual treatment [8]. Based on daily monitoring of PEF in patients with sudden, severe, life threatening attacks, the definition of brittle asthma was updated. Brittle asthma was defined as a diurnal PEF variability of $>50 \%$ on at least three days per week despite maximal medical treatment including high doses of inhaled corticosteroids with repeated doses of inhaled bronchodilator and maintenance or courses of oral corticosteroids [9]. This definition was more complete, however, it did not specify the doses of corticosteroids and inhaled bronchodilator; and it did not include sudden severe life threatening attacks on the background of apparently good asthma control. Later, the high doses of medical therapy were specified, and two phenotypes of patients with the severe disease were described $[10,11]$.

Type 1 brittle asthma is characterised by a maintained wide PEF variability (> 40\% diurnal variation for $>50 \%$ of the time over a period of at least 150 days) despite considerable medical therapy including a dose of inhaled steroids of at least $1500 \mu \mathrm{g}$ of beclomethasone or equivalent $[11,12,13]$. 
Type 2 brittle asthma is characterised by sudden acute attacks occurring in less than three hours without an obvious trigger on a background of apparent normal airway function or well controlled asthma [11, 12, 13] (table 1).

\section{Mechanisms}

Scientific reports published so far did not describe precisely the underlying mechanisms of brittle asthma development. The lack of the knowledge is mainly due to the high risk exposure and development of severe attack during the diagnostic procedures. Measurements of lung function, methacholine inhalation challenge and induction of sputum in patients with brittle asthma can be potentially dangerous since one forced expiratory manoeuver can be enough to cause significant worsening the of patient's condition.

Mechanisms behind the development of severe asthma have been studied thoroughly $[2,12,14]$. It is possible, that pathological events observed in brittle asthma may be similar to those occurring in severe asthma. The mechanisms of the sudden severe airway narrowing include smooth muscle contraction and edema of the airways, which are supported by chronic inflammation.

Smooth muscle contraction of airways is rapidly induced by many allergens; it is activated by a cholinergic reflex and by local release of tachykinins, substance $\mathrm{P}$, bronchoconstrictor and inflammatory peptides [15]. Edema of the airways occurs due to acute vasodilatation and plasma exudation from post-capillary venules as a result of anaphylactic reaction $[15,16]$. The chronic inflammation involves infiltration of the airway wall with different cells, mainly with eosinophils and neutrophils. Elevated eosinophils can be controlled by treatment with high doses of corticosteroids, while the count of neutrophils remain the same resulting in an alteration of the repair process, epithelial damage, extensive mucus plug and abnormalities of epithelial and endothelial permeability [12, 14]. Persistence of airway infiltration with eosinophils and neutrophils leads to fixed airflow obstruction or airway remodelling [1]. Airway remodelling is part of the structural alterations including subepithelial collagen and matrix protein disposition, smooth muscle cell hypertrophy, angiogenesis, and goblet cell metaplasia [17].

\section{Risk factors}

Mainly risk factors for type 1 brittle asthma have been presented in scientific publications. The risk factors for type 2 brittle asthma include only exposure to aeroallergens such as fungal spores and poor perception of the disease [12].

The majority of patients with type 1 brittle asth$\mathrm{ma}$ is atopic with the evidence of at least one positive skin prick test for cat, horse, wheat and chocolate allergens. Positive reaction to Dermatophagoides pteronyssinus is also possible; however, it is not specific for patients with brittle asthma [12]. More than half (over 60\%) of the patients are allergic to dairy products, wheat, fish, citrus, egg, potato, soya, peanut and yeast, which are the most common food triggers for brittle asthma [11].

Low levels of circulating IgG and IgA suggest an impairment of local immunity and increasing susceptibility to respiratory infections [12]. Respiratory tract infections can contribute to the severity of asthma and precipitate acute severe exacerbations $[3,7,14]$. There is some evidence to suggest that Mycoplasma pneumoniae may be found in patients with more severe asthma and could act as a perpetuating mechanism [18]. Persistant infection with Chlamydia pneumoniae is also associated with more frequent exacerbations of asthma and it can be another infection that worsens asthma.

Table 1. - Comparison of type I and type II brittle asthma

\begin{tabular}{|c|c|c|}
\hline Characteristics & Type I brittle asthma & Type II brittle asthma \\
\hline Definition & $\begin{array}{l}\text { PEF variability (> } 40 \% \text { diurnal variation for } \\
>50 \% \text { of the time over a period of at least } 150 \text { days) }\end{array}$ & $\begin{array}{l}\text { Sudden acute attacks occurring in less than } \\
3 \text { hours without an obvious trigger on a } \\
\text { background of apparent normal airway function }\end{array}$ \\
\hline Risk factors & $\begin{array}{l}\text { - Atopy } \\
\text { - Impairment of local immunity } \\
\text { - Increasing susceptibility to respiratory infections } \\
\text { - Psychosocial factors }\end{array}$ & $\begin{array}{l}\text { - Exposure to aeroallergens such as fungal spores } \\
\text { - Poor perception of the disease }\end{array}$ \\
\hline Patients & Women aged between 15 and 55 years & Equally prevalent in men and women \\
\hline Morbidity & High & - \\
\hline Mortality & - & High \\
\hline Treatment & $\begin{array}{l}\text { - Inhaled and/or oral steroids } \\
\text { - Inhaled bronchodilators } \\
\text { - Control of allergen exposure } \\
\text { - Immunotherapy } \\
\text { - Insurance of patient's compliance }\end{array}$ & $\begin{array}{l}\text { - Control of allergen exposure } \\
\text { - Identification of triggers } \\
\text { - Self management and management of acute } \\
\text { attacks }\end{array}$ \\
\hline
\end{tabular}


Psycho-social factors play an important role, depressions, frequent evidence of broken relationships and physical and sexual abuse are often in patients with type 1 brittle asthma $[11,12,16]$. The nature of psycho-social disorders remain unclear. It is difficult to distinguish whether brittle asthma is associated with personality disorder or whether asthma itself induces psychological instability [12].

Patients with the experience of severe attacks of asthma have a reduced perception of worsening airway function and reduced hypoxic drive, even when the lung function is normal, suggesting that during an acute attack they may not have a normal ventilatory response and delay taking the appropriate therapy $[12,19]$.

\section{Clinical picture and diagnosis}

Brittle asthma is recognised by sudden life threatening attacks on the background of wide PEF variability or apparent normal airway function and significant difficulties to manage the disease [20]. The diagnosis is based on the analysis of specific symptoms, role of triggers, personal or family history, measurement of lung function and PEF monitoring [21].

Type 1 brittle asthma is characterised by severe attack developed on the background of wide PEF variability (> 40\% diurnal variation for $>50 \%$ of the time over a period of at least 150 days) despite considerable medical therapy including a dose of inhaled steroids of at least $1500 \mu \mathrm{g}$ of beclomethasone or equivalent. PEF readings should be corrected for non-linearity when calculating diurnal variation [10]. Type 1 brittle asthma is more prevalent in women aged between 15 and 55 years [17], who have reduced values of total lung capacity and functional residual capacity at around $80 \%$ predicted [22]. Patients are frequently admitted for long hospital stays due to severe attacks and for assessment, stabilisation and prescription medication. Treatment with the high doses of inhaled and oral steroids leads to the development of glucose intolerance, weight gain and obstructive sleep apnoea [16]. Oesophageal reflux observed in patients with type 1 brittle asthma is a side effect of bronchodilators and increased negative intra-pleural pressures [6].

Type 2 brittle asthma is equally prevalent in men and women [16]. It is characterised by sudden acute attacks occurring in less than three hours without an obvious trigger on a background of apparently normal airway function or well controlled asthma. Hospital admissions are rare, erratic and occur at unpredictable intervals when patients develop sudden severe attacks of asthma. The attacks often impose risk of death and often require ventilation [16].

\section{Treatment of type 1 brittle asthma}

Patients with type 1 brittle asthma already receive treatment with the high doses of inhaled and/or oral steroids and inhaled bronchodilators, thus, application of the standard guidelines for asthma treatment is difficult [21]. Non-pharmacological treatment includes the control of allergen exposure, identification and avoidance of allergic food, good dietary support, immunotherapy and insurance of patient's compliance $[5,11]$.

The treatment begins with a control of allergen exposure and avoidance of food products of which the patients are intolerant [5]. Control of allergen exposure is difficult since many patients show resistance to exclude contact and exposure to animals.

Good dietary support is important for patients who eat a very restricted diet aimed at avoiding food allergens and controlling calorie intake. The excessive weight gain usually results from treatment with oral steroids. The diet of these patients should be complemented with minerals and vitamins to substitute significant deficiency of vitamins $\mathrm{A}$ and $\mathrm{E}$ and low intake of magnesium, selenium and vitamin $\mathrm{C}$ [23].

Scientific papers demonstrate that oral administration of immunomodulators like cyclosporine and methotrexate [5] or intravenous immunoglobulin [14] can relieve immunosuppression caused by the high doses of steroids. However, current guidelines do not recommend the use of aforementioned drugs for the treatment of asthma outside of new control trials. Methotrexate may have a small steroid sparing effect in adults with asthma who are dependent on oral corticosteroids. However, the overall reduction in daily steroid use is probably not large enough to reduce steroid-induced adverse effects. This small potential to reduce the impact of steroid side-effects is probably insufficient to offset the adverse effects of methotrexate [24]. Given the side effects of cyclosporin, the evidence available does not recommend routine use of this drug in the treatment of oral corticosteroid dependent asthma [25]. Current guidelines on use of intravenous immunoglobulin in human disease do not recommend the use of intravenous immunoglobulins for the treatment of asthma outside of new control trials [26].

Compliance with the treatment is a very important issue, in particular when management is extremely difficult according to the definition. The reasons for patients' non-compliance include lack of immediate benefit from anti-inflammatory therapy, fears of side effects and failure to take the prescribed treatment correctly [7, 27]. Patients with brittle asthma often try management tricks to avoid having to start or increase a dose of oral steroids [16].

Pharmacological treatment of type 1 brittle asthma in addition to the high doses of inhaled and/or oral steroids and bronchodilators includes subcutaneous injections of $\beta_{2}$ agonist and inhalation of long acting $\beta_{2}$ agonist.

Treatment with a long-term continuous subcutaneous infusion of $\beta_{2}$ agonist terbutaline at doses of 3-12 mg/day show significant improvement in PEF variation in about $50 \%$ of patients, and improvement of symptoms and reduction of other medications in $25 \%$ of patients $[5,16]$. Development of side effects including significant changes 
in serum potassium or glucose concentrations, tremor, muscle cramps with elevation of plasma creatinine phosphokinase, memory problems, ability to concentrate and occasional menorrhagia can be avoided by maintenance of the therapeutical range of terbutaline $[11,13]$. Many patients develop subcutaneous inflammatory nodules with eosinophilic infiltrate during continuous subcutaneous infusions. These usually settle down once that area of skin is avoided, but often leave a fibrotic nodule. In case of aggressive type of lesion, the formation of a clinically evident abscess containing sterile pus is observed [16].

Long acting inhaled $\beta_{2}$ agonists (salmeterol and formoterol) should be effective in type 1 brittle asthma in view of the wide variation in PEF and the success of terbutaline. However, salmetorol has proved to be disappointing in these patients for unknown reasons [16], while improvement of lung function and reduction of symptoms were documented for formotorol [28].

\section{Treatment of type 2 brittle asthma}

The treatment of patients with type 2 brittle asthma, that are relatively symptom free, includes control of allergen exposure, identification of triggers, self management and management of acute attacks [14]. Every patient should be supplied with a card providing relevant information because of sudden, severe, unexpected attacks that require emergent interventions.

The treatment of acute attacks includes immediate administration of adrenalin in preloaded syringes and administration of a bronchodilator [7]. Adrenalin has theoretical advantages over selective $\beta_{1}$ agonists, because of its action as an alpha adrenoreceptor against reducing airway edema [10]. Once adrenalin has been injected the patient should be advised to use a dose of nebulised salbutamol or terbutaline and proceed to causialty. In the case of acute respiratory insufficiency, mechanical lung ventilation is required.

\section{References}

1. The Global Initiative for Asthma. Pocket guide for asthma management and prevention. 2005. http://www.ginasthma.com/Guidelineitem.asp?11=2\&12=1\&intId=37

2. Wardlaw AJ, Brightling CE, Green R, Woltmann G, Bradding P, Pavord ID. New insights into the relationship between airway inflammation and asthma. Clin Sci 2002; 103: 201-211.

3. Bel EH. Clinical phenotypes of asthma. Curr Opin Pulmon Med 2004; 10: 44-50.

4. Mintz M. Asthma update: part I. Diagnosis, monitoring, and prevention of disease progression. Am Fam Physician 2004; 70: 893-898.

5. Gupta D, Ayres JG. Brittle asthma: a separate clinical phenotype of asthma? Indian J Chest Dis Allied Sci 2001; 43: 33-38.
6. Bel EH, ten Brinke A. The approach to the patients with refractory asthma. PCCU 20: lesson 4. http://www. chestnet.org/education/online/pccu/vol20/lessons03_04 /print04.php

7. Barnes PJ, Woolcock AJ. Difficult asthma. Eur Respir $J$ 1998; 12: 1209-1218.

8. Turner-Warwick M. On observing patterns of airflow obstruction in chronic asthma. Br J Dis Chest 1977; 71: 73-86.

9. O'Driscoll BRC, Ruffles SP, Ayres JG, et al. Long term treatment of severe asthma with subcutaneous terbutaline. Br J Dis Chest 1988; 82: 360-365.

10. Ayres JG. Classification and management of brittle asthma. Br J Hosp Med 1997; 57: 387-389.

11. Ayres JG. Brittle asthma: the management. Practice Nursing 1998; 9: 23-27.

12. Tillie-Leblond I, Gosset P, Tonnel AB. Inflammatory events in severe acute asthma. Allergy 2005; 60: 23-29.

13. Ayres JG, Jyothish D, Ninan T. Brittle asthma. Paediatr Respir Rev 2004; 5: 40-44.

14. Wenzel S. Mechanisms of severe asthma. Clin Exp Allergy 2003; 33: 1622-1628.

15. Graziani E, Petroianni A, Terzano C. Brittle asthma. Eur Rev Med Pharmacol Sci 2004; 8: 135-138.

16. Ayres JG, Miles JF, Barnes PJ. Brittle asthma. Thorax 1998; 53: 315-321.

17. Kenyon NJ, Jarjour NN. Severe asthma. Clin Rev Allergy Immunol 2003; 25: 131-149.

18. Kraft M, Wenzel SE, Bettinger CM, Martin RJ. The effect of salmeterol on nocturnal symptoms, airway function, and inflammation in asthma. Chest 1997; 111: 1249-1254.

19. Chung KF. Difficult, therapy-resistant asthma: definition and clinical features. Monaldi Arch Chest Dis 2000; 6: 459-465.

20. Hetzel MR. Brittle asthma: fiend or phantom? Thorax 1998; 53: 235-236.

21. Scotish Intercollegiate Guidelines Network, The British Thoraxic Society. British Guideline on the management of asthma. Quick reference guide. 2005. http://www. brit-thoracic.org.uk/Guidelinessince\%201997_asthma html

22. Miles JF, Sapiano S, Cayton RM, et al. Lung function tests in patients with brittle asthma. Am J Respir Crit Care Med 1995, 151: A676.

23. Backer JC, Tunnicliffe WS, Duncanson RC, Ayres JG. Dietary antioxidants and magnesium in type 1 brittle asthma: a case control study. Thorax 1999; 54: 115118.

24. Davies H, Olson L, Gibson P. Methotrexate as a steroid sparing agent for asthma in adults. Cochrane Database Syst Rev 2000; (2): CD000391.

25. Evans DJ, Cullian P, Geddes DM. Cyclosporin as an oral corticosteroid sparing agent in stable asthma. Cochrane Database Syst Rev 2001; (2): CD002993.

26. Orange JS, Hossny EM, Weiler CR, et al. Use of intravenous immunoglobulin in human disease: a review of evidence by members of the Primary Immunodeficiency Committee of the American Academy of Allergy, Asthma and Immunology. J Allergy Clin Immunol 2006; 117: S525-S553

27. Heaney LG, Robinson DS. Severe asthma treatment: need for characterising patients. Lancet 2005; 365: 974-976.

28. Ulrik CS, Kok-Jensen A. Different bronchodilating effect of salmeterol and formoterol in an adult asthmatic. Eur Respir J 1994; 7: 1003-1005. 